\title{
Commentary
}

\section{Reflections on shared parenting}

\author{
Vassilis K. Fouskas \\ University of East London, UK
}

"Only the law that is studied and no longer practiced is the gateway to justice"

Walter Benjamin, 1934/1999, p.815

\section{Introduction}

A better gift for Greek fathers in the runup to Father's Day on $21^{\text {st }}$ of June could have hardly been envisaged. Greece's justice minister, Constantine Tsiaras, announced the preparation of a civil rights bill for the reform of Greek family law, whose last substantive revision dates back to the PASOK (Panhellenic Socialist Movement) years of the early 1980s. ${ }^{1}$ Not that current Greek family law is terribly bad. PASOK's courageous reform of 1982-83, established gender equality and threw into the dustbin of history women's discrimination at all levels. However, with the passage of time, problems cropped up with the implementation of the law, as judges, influenced by the dominant sexist culture - according to which fathers were seen as unfit to look after their children - were overwhelmingly assigning custody of children to mothers only. For a mother to lose custody in Greek Courts meant that she had either to be proved to be a "sex worker" or a "drug addict". Shared parenting, as a presumption in law, after divorce was never considered, either because feminist groups within left-wing parties never pressed for that and/or because there were no any significant pro-father groups within those parties. A common perception cutting across Greek civil society was the belief that it is not in the best interests of the child to become a little ping-pong ball bouncing from one parental home to another. Thus, a "judges code" was created assigning custody to mothers only and visitation rights to fathers - usually once or twice a week for 3-4 hours and only during the day. Overnight stay with the father once a week was rather exceptional. This practice, notorious not only in Greece but everywhere in the world where joint custody is not a presumption in law, fomented a number of side effects - aside from the fact that it created first-and-second class citizens.

Clearly, the justifications for the reform of the Greek family law as presented by the Greek Minister draw on the legal framework for Children Rights and the pressure by the European Commission and Parliament on European governments. ${ }^{2}$ But this egalitarian-progressive framework - and pressures - have been in operation for many years, if not decades, and applied to all European governments. Syriza, in power for five years, did not act. The Labour Party in the UK did not lift a finger and even personal letters signed by Jeremy Corbyn as a response to pro-father pressure groups refused to endorse shared parenting. Right-wing parties across Europe are far more supportive of shared parenting. Why is that? What lies behind the refutation of the official centre-left to endorse a - by and large - progressive reform? It is argued here that the bill should be supported, but not uncritically. 
I begin with a discussion of three major flaws of the current family law system where shared parenting is not a presumption in law. Addressing these flaws alone, I argue, are sufficient to achieve a cross-party political consensus in support of reform. The second section addresses a critique of the bill based on its class implications. This analysis leads me to argue that the (liberal) reform of the family law, although progressive, cannot stand alone without a childcentric socialist political economy framework supporting the poor and the deprived. The commodification of family law, which the current framework sustains to the extreme, must be put to an end. Lastly, I speculate on why this liberal-progressive bill has not been pioneered by the neo-social democratic (liberal) Left, having instead become a Right-wing undertaking.

\section{Three major flaws in the current family law system}

First, middle and lower-middle class fathers who had dared to enter litigation demanding shared parenting/joint custody were not only risking losing regular access to their child(ren), but also could be required to make large child maintenance payments. As opposed to English law, the Greek family law system lacks a mathematical formula for determining child maintenance calculated according to the income of the non-residential parent, and in $98 \%$ of cases it is the father. The English system, which in many respects is far more antiquated than any family law framework in the West, splits down the middle all individual assets, both matrimonial and non-matrimonial. Thus, middle class fathers lose out in the division of assets after divorce, since mothers are assigned custody and 50\% of matrimonial and non-matrimonial assets.

The second observable flaw of the current family law system is the social practice of residential/non-residential parenthood and its side-effects to the detriment of children and nonresidential parent. In practice and for a number of reasons, children are often "weaponised" by the custodian/residential parent for financial gain, something which the Greek Minister made explicit in his announcement cited earlier. ${ }^{3}$ Although there is an enforcement mechanism for a non-residential parent who doesn't pay child maintenance (a criminal offence), there is no corresponding framework regarding the refusal by the residential parent to provide routine contact between the child and the non-residential parent (for example, the harshest enforcement laws regarding child maintenance are found in Germany and Canada). A common daily legal practice in Greece confirmed by my interviewees is the submission of maintenance applications overstating the non-resident parent's finances to get the judge to grant a large maintenance award to the residential parent. This process is not necessarily driven by the residential parent. Rather, because of the Greek system's review of child maintenance awards, it is driven by family lawyers favouring litigation every two years. Thus, the current laws governing family practice favour litigation over the welfare of the spouses and the child. As a result, lawyers' associations dealing with family law have no vested interest in supporting shared parenting. This increases the emotional distance between the non-resident parent and the child and the phenomenon of parental alienation. ${ }^{4}$ Parental alienation is widely recognised by think-tanks such as "Families Need Fathers" (England and Wales, see https://fnf.org.uk), "Synepimeleia" (Greece, see https://www.synepimelia.gr) or "National Parents Organisation" (USA, see https://www.nationalparentsorganization.org) as highly prevalent.

The third observable flaw in existing family law, in all countries that lack joint custody is that it allows the filing of Leave to Remove applications, which permit the custodian/residential parent, usually the mother, to legally remove the child from the jurisdiction in which the child habitually resides. By default, residential parents almost always have that petition/application approved; they are the residential/custodian parents and "primary carers" who are advised by 
solicitors in their Leave to Remove applications to point out that they have "anxieties" and "psychological problems of adaptation in the country". In essence, the argument, summarised perfectly in the famous "Payne vs. Payne" judgment of 2001 in England, is if the residential parent is unwell, then the child(ren) is unwell, so permission for parent and child(ren) to leave the country is granted. ${ }^{5}$ Clearly, this legal argument borders on sexism. This has been happening often in Greece, when a non-Greek marries a Greek citizen but then after divorce they decide to leave Greece and return to their country of origin. This is one of the most costly and protracted legal processes that induce couples to litigate endlessly over the custody of the children, in addition to the allocation of assets, child maintenance and so on. It can last for many months and even years.

\section{Why class matters}

What becomes abundantly clear is that legal practices around existing family law frameworks, based on single custodian parenthood, have become highly commodified. While it claims to be "child-centric", but it is not forcing parents to pay enormous legal fees, funds that might instead be used for the welfare of children. Yet, this process is applicable only to middle-to-uppermiddle class parents while poor families cannot afford litigation.

To a certain degree, the Greek bill benefits middle-to-upper-middle class fathers in several ways: they don't have to pay child maintenance and, in case their partner is also middle class, the division of assets would be more balanced and equitable. But this shared parenting bill cannot not have the same impact on lower middle classes, working classes and the unemployed families divorcing. For working class or unemployed couples the default position is one where the mother receives state benefits and, if at all, a small child maintenance from the father. In Greece and other countries of the global South, working class parents suffer more, especially mothers, as they end up having no child maintenance from the non-custodial parent (father) and few social benefits, if at all, from an effectively non-existent welfare state. More commonly in those societies, children end up being raised by the child's maternal grandparents. Thus, the law proposed by the Greek right-wing government will benefit neither the poor father nor their children without a robust welfare intervention either by the local communities or the state. Under current conditions of enduring austerity, ${ }^{6}$ governments shy away from state spending for welfare purposes writ large, let alone for the purpose of support of divorced families and children.

\section{Co-Parenting from the Right}

Here, then, lies one of the keys to understanding why a right-wing political party, such as New Democracy in Greece, is putting forth a progressive civil rights reform, a reform that should have been the banner of Syriza, a party with very few pro-social reform choices given its commitment to the programme of enduring austerity imposed by Brussels in summer 2015. Middle-to-upper-middle class parents, especially rich and super-rich fathers, do not have to worry about dividing their assets with their ex-spouse, or making child maintenance payments. Joint custody solves this problem without assigning any spending obligation on the part of the neo-liberal state. This is now the case within right-of-centre parties, or even extreme right-wing parties, like Germany's AfD (Alternativ für Deutschland), which supports shared parenting. In those parties, neo-liberal public policy views, coupled with conservative values of nuclear family, prevail and no such resistance against reforming the current family law is put forth. Thus, by addressing the issue of shared parenting head-on, the European right sustains a class balance in favour of the rich as it relinquishes welfare responsibilities and spending for the 
protection of the poor. At the same time, it proports that it is doing no harm to the best interest of the child, but as we have seen, poor children and families suffer. Shared parenting would be far more child-centric and preferable under the correct social and policy framework.

But what is going on in the internal regimes of centre-of-left parties, such as Syriza? Syriza, in power for nearly five years (January 2015 - July 2019), did not dare to change the family law, undermining the pathologies described above. The Labour Party in the UK is silent on the issue. ${ }^{7}$ One can understand why the legal profession, taking advantage of a legal framework of single custodial parenthood and its loopholes, is unsupportive of an egalitarian-liberal reform; but then why is the Labour Party silent? How can a party be the frontrunner of "gender equality", "positive discrimination" and "all-women short-list", to recall Clinton's and Blair's slogans of the 1990s, without also pursuing gender parental equality? Jeremy Corbyn, unlike George Galloway, refused to support shared parenting. "Identity politics" of all kinds, duly criticised by Eric Hobsbawm in the 1990s, are very much consolidated within the parties of the liberal Left (Hobsbawm 1996). The same, with some understandable cultural variations, goes for Syriza's inner-party liberal establishment and other left-of-centre parties. But this perspective weakens social/class analysis in the formulation of policy and party strategy and undermines class solidarity in familial relations during marriage and after divorce.

Identity politics and absence of pro-fathers' groups inside the parties of the Left paid lip service to the cause of gender parental equality, at the moment when neo-conservative elites were decimating welfare services and proletarianizing parenthood in conditions of enduring austerity. Covid-19 has intensified the crisis of the family and created a new army of unemployed people, especially in the transatlantic economies. ${ }^{9}$ Over the years, the erosion of the manufacturing base of western societies, coupled with the decline of Fordism and Keynesianism, reshuffled the social/technical division of labour, creating new demands and bringing new players in the market, "previously excluded by discrimination along racial, ethnic and gender lines" (Brenner 2017: 6). Supply-side economics have "returned to the private sector activities that had long ago been taken over by the state, such as health care, education, and infrastructure" (Brenner 2017: 7). ${ }^{10}$ The commodification of family relations intensified with the takeover of childcare by private nurseries and child-minding services. Free-market capitalism and the new services economy became a site in which women's liberation from family fetters, obligations and patriarchy found expression and meaning. The critical/class perspective of this process, which entails recognition of the proletarianization of both sexes, was brushed off by the parties of the Left in favour of identity politics, endorsing a pronounced shift towards a "culture of narcissism", as Christopher Lasch put it long ago. ${ }^{11}$ This culture, coupled with relentless consumerism and a media-driven campaign to spend and consume, even if individuals have to borrow in order to spend/consume, is spread across all social classes and communities, whether urban or rural. ${ }^{12}$ In this cultural and social contexts, the preferred pattern after divorce continued to be diverting the father's child maintenance to paying external agencies (cleaning services, baby-sitters, education etc.), rather than accepting and promoting shared parenting, which entails a fundamental cultural shift towards gender parental equality and an understanding of society as a society divided into classes in which children view their parents equivalently. Further, an understanding of the social tissue as a class and gender interdependency, brings to the fore the injustices created by neo-liberal public policy-making and the market, which necessitates strong injections of socialism in order to counter-balance gender, class and other inequalities. By dropping the class-referent, the neo-social democratic "Third Way" Left failed to put forth the good cause of shared parenting, leaving instead the Right to capitalise on it from its own class perspective. Thus, it is no accident that a new type 
of womanhood and motherhood is put forth by a number of highly educated women, supporting openly "men and boys". ${ }^{13}$

\section{Final touches}

The new family law bill that the Greek Right is poised to institute this coming autumn will eradicate all the three major pathologies analysed above, benefitting, first and foremost, children. In particular, it has the potential to fight the commodification of family relations and extravagances of the legal profession, especially if welfare-socialist support in poor families strengthens. No doubt, there are many other pathologies and legal loopholes which cannot be given due attention in this short commentary because of lack of space. However, the new shared parenting legal framework is far from blameless. Its most serious flaw is the absence of a class problematic: shared parenting does not have the same implications across social classes. ${ }^{14}$ Shared parenting means nothing for a poor mother and father if they are unemployed and decisions are implemented without social welfare and/or community support. Liberal law always needs a strong injection of socialism in order to address class inequalities articulated in complex gender and family relations, especially in conditions of enduring austerity. There is no such thing as "just law", as every legal framework reflects class and power relations. This is how one should read Benjamin's opening retort that "only the law that is studied and no longer practiced is the gateway to justice".

I have also suggested that the Left failed to pioneer the reform of family law because of the prevalence of identity politics after the end of the Cold War and a rather classless vision of political struggle developed under the leaderships of Blair and Clinton in the 1990s. I have also suggested that the absence of organised group of fathers within Left parties pushing for shared parenting after divorce contributed to the passive attitude of the Left on the issue. The Right faced no problem acting according to the class interests it represents, while supporting the best interests of children. Thus, a good progressive cause for the Left was lost. It is high time for the Left now, in conditions of enduring austerity, neo-liberalisation and Covid-19 to inject a strong dose of class analysis and class political practice in gender and other relations, previously isolated and self-identified as if they existed in a class vacuum.

Lastly, I argued that, despite its practical problems, the new Greek family law should be supported, regardless of its political-party provenance. It relieves both parents from very large (and onerous) financial legal fees and avoids a practice that can alienate children from one of their parents. We must challenge the presumption that living with the child's mother is automatically best. The old system of creating residential/non-residential parents continues sexist assumptions about the role of women in caregiving. It fails to capture the social/technical division of labour in which almost $50 \%$ of the workforce are women.

\section{References}

Athens Voice (2020) https://www.athensvoice.gr/politics/657118 tsiaras-yper-tissynepimeleias-ton-paidion-diazeygmenon-goneon (accessed on 20 June).

Benjamin W (1934/1999) "Franz Kafka" in Selected Writings, v.2, edited by Michael W. Jennings, Howard Eiland and Gary Smith, Cambridge MA: Harvard University Press/Belknap Press 
Bolch J (2014), "Important family law cases: Payne v Payne", Stow Family Law, UK https://www.stowefamilylaw.co.uk/blog/2014/07/16/important-family-law-casespayne-v-payne-by-john-bolch/ (accessed on 19 July 2020)

Brenner R (2017), “Introducing Catalyst”, Catalyst, 1:1: 1-19, Spring

Cohen, E. (2020), "Why the coronavirus pandemic is leading so many couples to divorce", New York Post, 23 May.

Good Egg Safety CIC (2020), “Report on parental alienation”, London [mimeo]

Harman J J. Harman, W B and J Harman (2019), "Parental alientation: The blossoming field of study", Current Directions in Psychological Science, 28: 2: 212-217

Hobsbawm E (1996), "Identity politics and the Left", New Left Review, 217, May-June

Jessop B (2019), "Ordoliberalism and neoliberalisation: governing through order or disorder", Critical Sociology, 45: 7-8: 967-982

Krippner G R (2011) Capitalising on Crisis. The Political Origins of the Rise of Finance, Boston, MA: Harvard University Press

Lasch C (1977), Heaven in a Heartless World. The Family Besieged, New York, NY: Norton

Lasch C (1979), The Culture of Narcissism. American Life in an Age of Diminishing Expectations, New York, NY: Norton.

Loftis L (2015), "Mothers speak up for their sons - and enrage hard-line feminists", The Conservative Woman, 5 March.

O’Connor M (2019), “Jeremy Corbyn opposes equal rights for dads”, Fathers4Justice, https://www.fathers-4-justice.org/2015/08/jeremy-corbyn-opposes-equal-rights-fordads/ (accessed on 21 June 2019)

Streeck, W. (2016), How Will Capitalism End? London: Verso

\section{Interviews}

Andreas Kioupis, Greek barrister and expert in family law, Athens, Greece, 25 July 2019 Vasileios Panoulas, Greek barrister, Arta, Greece, 18 April 2016

\section{Endnotes}

\footnotetext{
1"Tsiaras: I'm in favour of joint custody", Athens Voice, 19 June 2020 https://www.athensvoice.gr/politics/657118 tsiaras-yper-tis-synepimeleias-ton-paidion-diazeygmenongoneon (accessed on 20 June 2020).
} 
${ }^{2}$ See, United Nations Convention on the Rights of the Child (UNCRC) https://www.unicef.org.uk/what-wedo/un-convention-child-rights/ (accessed on 27 June 2020); importantly, see the EU framework on shared parenting as set out by the European Parliament in Resolution 2079/2015, "Equality and shared parental responsibility: the role of fathers", http://www.europeanrights.eu/public/atti/2079-riso-ingIPDF.pdf (accessed on 27 June 2020)

${ }^{3} \mathrm{I}$ 'm relying here on witnesses by the legal profession in Greece. Two barristers practicing family law have kindly accorded me interviews: personal interview with Greek Barrister, Vasileios Panoulas, 18 April 2016, Arta, Greece; personal interview with Greek barrister and expert in family law, Andreas Kioupis, 25 July 2019, Athens, Greece.

${ }^{4}$ See especially, Harman, et al 2019. For contemporary empirical researches, see "The UK parental alienation study" https://fnf.org.uk/index.php?option=com content\&view=article\&id=606:biggest-ever-uk-parentalalienation-study-published\&catid=2. This report was commissioned by Good Egg Safety CIC, an independent think-tank, supported by Families Need Fathers, a UK government charity. It is based on 1,500 questionnaire responses by separated parents and is gender-balanced. The Chair of Good Egg Safety CIC, Jan James, believes that "parental Alienation is an international scandal and one which can damage children for life" (see:

https://parentalalienationuk.info/, accessed on 26 June) 2020). One could argue that parental alienation kickstarts from very early stages, once the child realises that his or her parents are about to separate. I'm thankful to Rosemary Bechler for this observation.

${ }^{5}$ The case, comprehensively summarised by John Bolch (2014) of the Stow Family Law firm in the UK, reads as follows (apologies for the long quote but it is necessary in order to fully understand a complicated case): "The father was British and the mother was a citizen of New Zealand. The mother came to London when she was in her early twenties. She met the father and they were married in 1996. Their daughter, S, was born in 1997 and the mother gave up work to look after her. At some time after $\mathrm{S}$ was born the parents decided to move abroad. Exactly what was decided was in dispute. The mother said that they had all decided to live in New Zealand, after the husband had first carried out a contract in Kuala Lumpur. The father's case was that the stay in New Zealand was to be exploratory, with no firm commitment, especially as his work prospects in New Zealand were uncertain. Whatever, the mother and S left for Auckland and the father for Kuala Lumpur. The mother and S were in New Zealand for about fourteen months, from March 1998 until May 1999, and the father moved there in August 1998, after he completed his contract in Kuala Lumpur. However, by that time the parents' relationship had broken down and they separated within a week of the father arriving in New Zealand. The mother then applied to the court in New Zealand for custody and an order preventing the father from removing $\mathrm{S}$ from New Zealand, and the father made a cross-application for custody and permission to remove $S$ from the country. The judge did not find the mother a convincing witness, and thought it likely that even before the family left England she had decided to separate from the husband once they got to New Zealand. He ordered that S should be returned to the United Kingdom and she travelled back in May 1999, accompanied by both parents. On arrival in England the father went to Newmarket, where other members of his family lived, and the mother told him that she was taking $S$ to stay with her uncle and aunt in Finchley. In fact, the mother took $S$ to another address, which was unknown to the father. However, with the help of the police, the father traced the mother and $\mathrm{S}$ within a few days. Proceedings then took place in the Cambridge County Court and in June 1999 a residence order was made in favour of the mother, by consent, with a prohibition against her removing $S$ from the jurisdiction. A contact order was also made in favour of the father and it was accepted by all that the contact thereafter went 'exceptionally well'. $S$ also had a strong attachment to the paternal grandmother. The mother, however, was not happy in England and indicated through her solicitor that she wished to relocate with $\mathrm{S}$ to New Zealand. The father then applied to vary the residence order in his favour, claiming "that the mother was not discharging her responsibility satisfactorily and that he could do better". The mother responded by issuing a cross application for permission to relocate with $\mathrm{S}$ to New Zealand. The judge refused the father's residence application and granted the mother permission to remove $S$ permanently to New Zealand. He found that if she remained in England the mother's 'unhappiness, sense of isolation and depression would be exacerbated to a degree that could well be damaging to the child'. As to the father, he would be able to afford to visit S or have her visit him two or three times a year, 'which mitigated the loss to the child and to him'. The father appealed. The Court of Appeal dismissed the father's appeal. What became the most important part of the case was contained in the judgment of the then President of the Family Division Dame Elizabeth Butler-Sloss, when she summarised the guidelines to be followed in relocation cases. She set them out as follows: (a) The welfare of the child is always paramount. (b) There is no presumption in favour of the applicant parent. (c) The reasonable proposals of the parent with a residence order wishing to live abroad carry great weight. (d) Consequently, the proposals have to be scrutinised with care and the court needs to be satisfied that there is a genuine motivation for the move and not the intention 
to bring contact between the child and the other parent to an end. (e) The effect upon the applicant parent and the new family of the child of a refusal of leave is very important. ( $f$ ) The effect upon the child of the denial of contact with the other parent and in some cases his family is very important. (g) The opportunity for continuing contact between the child and the parent left behind may be very significant. Importantly (and as is sometimes overlooked) Dame Butler-Sloss went on: 'All the above observations have been made on the premise that the question of residence is not a live issue. If, however, there is a real dispute as to which parent should be granted a residence order, and the decision as to which parent is the more suitable is finely balanced, the future plans of each parent for the child are clearly relevant. If one parent intends to set up home in another country and remove the child from school, surroundings and the other parent and his family, it may in some cases be an important factor to weigh in the balance. But in a case where the decision as to residence is clear as the judge in this case clearly thought it was, the plans for removal from the jurisdiction would not be likely to be significant in the decision over residence. The mother in this case already had a residence order and the judge 's decision on residence was not an issue before this Court.' What all of this boils down to is that where a parent with whom the child is residing puts forward genuine, reasonable proposals to relocate then they will usually be allowed to do so. Payne has been heavily criticised for placing too great an emphasis on the wishes and feelings of the relocating parent, a fact that constitutes sexism. See, John Bolch (2014)

${ }^{6}$ The term belongs to Bob Jessop (2019)

7 The 2019 Manifesto of the Labour Party, the most radical statement in the party's political history after the end of the Cold War, is silent on the issue of shared parenting and family law. In general, Labour Party committees and reports on inequality tackle issues such as gender pay gap, transgender rights and so on. Not a single document in the digitised Labour archives on "Women and equality" tackles the issue of shared parenting; see, Labour Party, "Women and Equality", https://labour.org.uk/category/latest/pressrelease/women-and-equalities/ (accessed on 27 June 2020).

8 In August 2014, unlike other Labour Party MPs, Jeremy Corbyn, at time a member of the Parliament's Justice Committee, in a letter to one of his constituent members revealed by the pro-father militant UK group, Fathers4Justice, refused point blank both shared parenting and the strengthening of the legal position of grandparents. See, Matt O'Connor (2019)

${ }^{9}$ See, Cohen (2020). The author correctly identifies the problem but the analysis regarding the causes of family breakdown in Covid-19 conditions is plainly wrong. In the USA, Covid-19 caused unprecedented unemployment.

${ }^{10}$ Wolfgang Streeck (2016) develops a similar problematic.

${ }^{11}$ Christopher Lasch, a contrarian sociologist, cultural historian and a critique of the modern liberal-Marxist idea of progress, wrote marvellous pages in support of family as a unit of love and a heaven in a heartless world. He saw the culture of narcissism and the proletarianization of parenthood as derivatives of technological progress, bringing about the dissolution of the nuclear family and the corruption of true individual happiness. See, among others, Lasch 1977, 1979

${ }^{12}$ As high wages sustaining mass consumption is no longer the case in post-Fordist conditions, consumption of either necessities or non-necessities and general consumption of goods is based on access to credit (e.g. house mortgages). This is the phenomenon of "financialisation of every-day life", in which households and individuals are induced to borrow in order to consume, even commodities that do not need and/or don't constitute necessities for their social reproduction. As neoliberal ideology goes, each family member should own a car so that no one is dependent on the other; see, among others, Krippner (2011); also, Streeck (2016).

${ }^{13}$ One would find many interesting articles in publications such as, The Conservative Woman, where "boys and fathers" are defended against radical feminist currents which continue to fight against an embattled male identity that leads to an increased rate of male suicide, male victims of domestic violence and so on. Characteristic, in this respect, is the piece by Leslie Loftis, "Mothers speak up for their sons - and enrage hardline feminists", The Conservative Woman, 5 March 2015. Time and again, the class problematic is absent, something which is understandable in centrist, liberal and conservative systems of thought. But it is not justified among the Left.

${ }^{14}$ We did not examine at all the issue of culture, particularly ethnic and religious culture, but it is a very serious issue that deserves further discussion.

For Correspondence: Vassilis K. Fouskas, School of Business \& Law, University of East London, University Square, 1 Salway Road, London E15 1NF, UK, email: v.fouskas@uel.ac.uk 